\title{
ISSUES AND ETHICAL PROBLEMS OF STEM CELL THERAPY - WHERE IS HIPPOCRATES?
}

\author{
Lucie Rousková ${ }^{1}$, Ivan Hruška², Stanislav Filip ${ }^{1}$ \\ Charles University in Prague, Faculty of Medicine and University Hospital Hradec Králové, Czech Republic: Department \\ of Oncology nad Radiotherapy ${ }^{1}$; University of Hradec Králové, Czech Republic: Faculty of Arts ${ }^{2}$
}

\begin{abstract}
Summary: Stem cells and their therapeutic use present many questions associated with ethical problems in medicine. There is great effort on the part of physicians to help millions of patients while there are ethical problems with the use of new methods and technologies and all of these are affected by economic and political influences. How will the current generation deal with these problems? Medicine, in this begard, is experiencing a stormy evolution of human culture in the relationships between disease, patient and doctor. Philosophy approaches the same juncture of human culture, but seemingly from the other side. Both disciplines are facing a great problem: How to unite the content of current human morality and the desire for health? Both philosophers and physicians perceive this deficit in human culture as it does not provide immediately usable normatives, which the living generation of healthy and ill is waiting for. It may be said that medicine, as many times before, has reached a stage where it cannot rely only on the proved axiologic values from the past, ethical normatives or cultivated moral sense of its subjects. Medicine has no other alternative than to take an active part in resolution of interdisciplinary problems originating from philosophic-biologic or philosophic-medical inquiries of axiologic, ethical, and moral issues. Our paper indicates some ways of the search in forming ethical principles of the stem-cell therapy from the view of biologists and physicians. New ways are recommended in theoretical-methodological interdisciplinary research, especially, in theoretical and experimental biology, and theoretical and clinical medicine, as well as philosophy. In this paper important ethical problems are pointed out in order to find answers to some key problems connected with cell therapy and the use of stem cells.
\end{abstract}

Key words: Stem cells; Adult stem cells; Embryo, Cloning; Stem cell therapy; Ethical issue

\section{Introduction}

The common denominator of many philosophic approaches to the problem of human embryos used in medicine is the problem of "whether it is of full human value, deserving respect as a human being" or not. Whether an embryo has a definite identity in which it may start its own coordinated gradual development or is only a cluster of cells. If integrity or holistic properties of cells in an early embryo are considered, they are in fact not only the cluster of pre-embryonic structural parts but a sum of cells. They have their own inherently encoded evolution which is not rigorously predetermined. In other words, the autointegrity of evolution and the proportionally predetermined evolution of an embryo do not make it a "living thing" able of independent existence. A human foetus since the first moment of existence goes through many qualitative (externally or internally determined) transformations before becoming a definitive human entity (38).

Animal embryos created for research purposes should be legally and organisationally secured so they cannot be mistaken for therapeutic cloning $(2,3,39)$. Probably, a semantic distinction may be helpful expressing a partial use of embryo ("part-embryo-cloning" or "regenerative part-embryo medicin") (34) if the term therapeutic cloning, which reminds one of the effort to make an embryo an evolutionary and full-value unit is not already left (11).

The main interest is not in the embryo itself. Humans, during their lifespan, are able to produce huge amounts of embryo. Actually, a surplus of eggs plus surplus of sperm give a certain surplus of embryos and only a few reach the final stage. This biological over-supply is understandable as is the reason to use this surplus for treatment and research for the benefit of the sick. Medicine has been ever present since the dawn of man and the Hippocratic oath was created for the respect of the sick. The evolution of man and his society cannot be stopped, just as new therapeutic discoveries cannot be. Generally speaking,"the value" of birth, life and death is higher than that of surplus embryos. This is confirmed by axiology of evolutionary ontology Therefore, the question is how to find ethical normatives in cultural society? Surely, "the value" of something or somebody has dif- 
ferent aspects, and here is the origin of one of the main problems: The value as a normative dimension in cultural society is related to both the individual and the whole society $(12,33)$.

\section{Stem cells and „untouchability“ of human life}

Mankind is at the forefront of evolution and directly affects his own fate. But can mankind interfere in this evolution (or evolution within him) so as to change the rules, to change spontaneous mechanisms of functioning? Such uncompromising fomulations present philosophy, ethics, politics, law, and particularly medical research and therapy with the dilemma of whether or not to use stem cells in cellular therapy. Mankind has made substantial progress in the sciences and therapies, and traditional emotive alternatives and historical examples give no ethical answers any more. This situation is quite new, and for scientific methodology exceptionally demanding. To date, neither philosophy, ontology and neoethics, nor theoretical concepts in biology and medicine are able to solve this situation (48). Biomedical experimental studies in the field of stem cells and newly discovered possibilities of their use have gotten ahead of standard ethical and clinical recommendations. Stem cells with their contents are directed at the bioevolutionary base of human existence. And here is the origin of the important question reaching far beyond the frame of stem cells: How are laws and principles in physics, biology and medicine linked up with human existence (36)?

The branch of medicine named regenerative medicine includes cell therapy and also therapeutic cloning (22). Biologic models and evolutionary potentials are used to investigate and verify methods of embryogenesis or other evolutionary phases immediately followed by other phases of the developing organism (27).

The aim is to get a certain insight into the specific causality of formation and growth of tissue structures which may lead to the development of their substitutions for tissue repair and, ultimately, for the patients' benefit (52). To that purpose, stem cells obtained by different methods are used. It is the opportunity to study some aspects of the behaviour of cell systems (41). These cells may be considered an intermediate stage of tissue differentiation in the time between fertilization and birth. In the cell therapy, after their application, some of these cells are "used" to form specific tissues and some remain unchanged in the organism as if "asleep" ("evolutionary sleep of an organism"). Although all connections of their development, maintenance and use in the organism are yet unknown to modern medicine, the progress of knowledge is undisputable. Namely, stem cells were tested in haematopoiesis, myogenesis and, what is more, without the risk of negative immune responses (17). There are no real objections to this part of the problem. The real problem is the final use of stem cells with regard to the patient's benefit. Nevertheless, among laymen and the scientific public, questions and worries about justification of using certain resources and certain methods of stem cell acquisitions are increasing. Here, the plasticity of stem cells may have a decisive role in their possible therapeutic use $(14,15,47)$.

Mostly negative reactions occur in cases with embryos containing stem cells with the greatest potential of plasticity $(34,38,43,51)$. In other words, it is not the question whether our intervention into the evolution, even scientifically justified, should be done, but the important question is why? Who would get the benefit, or what is the goal? Such interventions have been made by humans since their very existence and usually unintentionally. Now it is about how people would tolerate stem cell acquisition for therapeutic purposes or would they prefer less effective and to date less investigated resources without the slightest intention to clone an entite person.

Embryonic stem cells are acquired by several means. The most frequent is the use of "surplus" embryos after assisted fertilization (20). Eventual voluntary donorship of eggs and sperm is at the beginning, as well as creation of embryos determined for differential clonal yield. There are also single approaches trying to use oocytes of other animal species for production of human cells (19). Another possible way to acquire embryonic cells may be isolation of human gamets directly from hES (human embryonal stem cell) cell cultures $(8,26)$.

Anti-abortionists refuse such methods, even if the donorship is voluntary on one hand and therapeutic useful on the other (research needs are not recognized). This situation is the result of different cultural traditions where ontogenesis interruption of already fertilized foetus is considered unsuitable (31).

Such ethical judgements are understandable in cases when the only intention is to produce a child. Nevertheless, despite the complexity of evolution and human culture, the breach of this principle is known. In many countries over the world artificial interruption of pregnancy is legal just in order to maintain the mother's health and quality of her life or to fulfil the parents' wish to bear and breed a child according to their ideas of its well-being (27).

The situation of embryonic stem cell collection is quite different: one thing is the chance to improve therapeutically the quality of life of a living sick human being, another is voluntary intentional activity of donors of embryos and medical teams (from fertilization to removal, use of its stem cells and destruction). There is no intention to interrupt having a child but to realize the intention to help an ill human being by ways currently available in medicine. This should be scientifically and ethically justifiable. The problem is to produce embryos for therapeutic intervention aimed at the benefit of the existing life, not for inception of new life. Another problem with the use of embryonic cells is the counter argument that this foetus did not evolve by a natural way but by another method such as the technology of cloning. That is a much broader ethical problem than 
the natural way of fertilization and development of the embryo. There are also other unresolved issues we must not forget: organ transplantations or several ethical problems that medicine has had to solve (13). By answering them we may find some other ethical solutions (such as the relation of donor-recipient in allogeneic bone marrow transplantation) or their possible adaptations for use in the cell therapy.

The use of adult stem cells offers a certain "bio-ethical" solution. Stem cells, obtained from adult differentiated tissues, have lower potential for plasticity and therefore for therapeutics. On the other hand, they are more easily acquired and carry substantially lower risks after transplantation. Autologous transplantation is possible (15).

Currently, in order to maintain the necessary level of cell plasticity, there is no method to separate the adult stem cell system and embryonic stem cell system and their products. But this situation is only temporary and solves only a part of the problem of stem cell source. Other necessary steps (induction of plasticity in tissue specific stem cells, such as neural stem cells) require, among other things, further partial methodic instructions, some of which were elaborated under our laboratory conditions $(17,35)$.

The problem of parents and their rights or the rights of society is another problem for anti-abortionists. What normatives must the parents' decision making have and what is their right to the supreme control of foetuses they have produced? In natural situations, it is the "credit" of parents and the process is in accordance with the bio-evolutionary nature of the mother to carry her child. Realisation of assisted artificial fertilization shifts this question. Usually, the reason is the mother's right to decide, to have the last word, whether she wants the baby. This is established in legal and liberal amendments (permitting abortions with medical assistance in certain defined social circumstances). Contrary to this, the rights of an unborn child are sometimes pointed out even if this is the foetus that has the chance to become a healthy born child. These rights are covered by different restrictive laws in legal systems (fully or partially forbidding abortions, with exceptions of incest, rape etc.). The real impact of this legislation is an increase of illegal abortions, difficulties in obtaining legal abortions, but there is no complete stop to all abortions. These abortions are performed probably from deeper social motives than the law reflects. Optionally, the rights of fathers are discussed connected with their views on abortions. The question of the rights of the society, namely, of human culture, is lacking. The culture of society does not occur automatically but through human endeavour and mostly is realised in millions of partial and particular interests of people $(15,34)$.

To protect the development of a population or populations is another topic for discussion. A possible objection or counter argument may be that regenerative medicine is not about 'embryos' as such but about therapy of patients treated by medical means. Both evolution of new human beings and new methods to treat diseases (or maintain health) belong to the domain of protection and support of health. Human culture itself associated with medicine is subject to further intensive evolution. In other words, the therapeutic use of one embryo may not be a great loss for the living human population, but from the patients' view may even be considered a success $(15,23)$.

Another problem from the aspect of both bio-evolution and human culture is the surplus of gametes. A female organism produces hundreds of eggs during her natural lifetime, and most of them are not used. This natural abundance and natural "waste" is quite often seen in nature. A male organism produces millions of sperm during his normal development and only one is needed for the development of a new individual. This "abundance" has been present long before man was able to raise this ethically important question. Now, medicine faces the issue of whether to use this natural abundance in treatment of diseases and thereby support the quality of life. However, the question is whether to use ways that have developed during the evolution process or ways associated with new scientific knowledge. These ways together present a new view on evolution of man and society $(15,32)$.

Financial support and private or state control of research also present a problem that is theoretically important, politically, legally, socially and medically: state control over research funding or control by private investor. How to estimate what is more advantageous? There is one example from history showing the situation with control and funding of chain reaction leading to atomic bomb development. This research was state funded and controlled. Private research not controlled by state and the public may bring publicly uncontrolable results. In formal logic this assumption is not explictly true. It is not only about the amount of funds. We will focus on the importance of consequences measurable by the range of utilization of embryonic "yields" in regenerative medicine. At the moment it is apparent that the quality of medicine and quality of treatment cannot be decided by market forces or by social demand with the most noble motives. Throughout history, tax and legal systems have developed ensuring public control of activities which are to be funded and controlled by evolving society as a whole $(18,29,30,46)$.

\section{Stem cell and an emipirical view on ethical rules, research and therapy}

An alternative to harvesting stem cells in different stages of evolving tissues from human organism (for medical research and therapy) brings unequal conditions of their utilization from the viewpoint of biology, medical therapy, organization, funds, and not least, ethics $(3,32,46)$. Despite ethical committees being established for problems of biomedical research in general, more and more problems, understandably, accumulate around questions of using human embryos. The desire to have children, even for people with limited fertility, is a strong motive in all generations and all 
human subcultures. Nevertheless, the finding of in vitro assisted fertilization technique brought also certain "sideeffects", among others, acquisition of embryos for other therapeutic purposes. That is probably why today the principal goal is to determine, unify, observe and control strict regulations on manipulation with the socalled "laboratory embryos" in the research and medicine $(9,18,30,46)$.

Stem cell biology and cell therapy, apparently, are coming to age and raise new hopes as well as probléme, some of which we would like to illustrate, for example on myocardial infraction $(15,17)$. Myocardial infraction is a disease leading to the loss of tissue and impairment of heart perfomance. Residual cardiomyocytes are not able to reconstitute the necrotic tissue and heart function gets worse with time. According to some theories, distant stem cells activate damage to the target organ, migrate to the injured site and undergo there alternative differentiation. The idea to regenerate the damaged heart tissue by addition of cells is not new, but to find cells able to fulfil this task is difficult. The idea to use bone marrow stem cells for heart regeneration is particularly attractive. Harvesting of cells from bone marrow in adults is easy and routine and does not present any ethical problems connected with the use of embryonic and foetal tissue (17). The therapy with cells from the patient's own bone marrow eliminates the fear of tissue rejection (a great problem with cells from another donor). Critically evaluating clinical studies on cell therapy of myocardial infraction Publisher to date, we have to realize that it will not be easy to find a cell population or cytokine cascade which would enable us to better utilize the possibilities that cell therapy offers. The results of studies are different in both clinical and biological aspects. The number of patients is small and application of cell (myocardial injection or intracoronary infusion) is also different and the transplant itself is different (either bone marrow cells, muscleobtained myoblasts or separated progenitor cells). However, the most important problem has not been solved yet: what are the condition to accept this method. Many experiments will be needed before it becomes an important part of the stem cell therapy (15).

These therapeutic procedures can be carried out only under clear ethical conditions, with addition a ethical requirements of a given country or subculture. Scientists and politicians may create a necessary and useful climate for the research of human embryos. Namely, for collection of embryonic stem cells ( $\mathrm{such}$ as biopsy of 1 cell from the embryo at the stage of 4-8 cells, etc.), allowing for the rest of the embryo to be destroyed after this procedure (as it cannot be used for assisted fertilization). In the world, potential scientific and public (moral) agreement with this procedure is ever increasing, especially, in connection with the development of promising effective therapies of insidious and previously untreatable diseases in children and adults. It is surprising how ineffective the support of this type of bio-medical research is by many governments. This has caused certain indecision and blocking of government funds in several such programs $(7,9)$. Much American research speaks about the restraint placed upon stem cell research of pushing it beyond standard economic conditions $(1,6,10,24,28,45)$.

Political and economic stress concerning stem cell research and the search for alternate ways of harvesting either from adult human tissues $(27,44,53)$ or from embryonic tissues $(25,50)$ creates very unstable situations (21). Moral principles of scientists, physicians and politicians are exposed to heavy pressure. Millions of patients with diabetes mellitus, degenerative diseases of the nervous system and brain, tissues and other diseases stand in front of hospital gates waiting for help. Suitable therapies, however, are still at the research stage. This pressure creates a great social pressure also in cultural society and may lead to non objective (illusory) conclusions and exaggerated euphoria associated with some experimenal results, such as when hES cells are transplanted to an experimental animal or when cultured in vitro in a suitable medium may differentiate into three germinal layers (49) and so become an unlimited source for cellular therapy. These and other results have met with a huge public response in both scientific and political circles. Very promising ideas of presumed applications have been formulated, opening new ways for treatment of serious diseases (51). However, experiments on animal models showed that therapeutic use of stem cells may have its own risks, such as the development of cancer leading to formation of teratomas $(14,25)$. We must not underestimate these risks. For that purpose it would be necessary to prepare lines of secondary specialized cells according to actual need, which would be quite time-consuming. Even if these obstacles are overcome, it would not be easy to acquire compatible stem-cell lines and to avoid one of the greatest threats of transplantations, immune rejection, especially if other interventions would be needed to control immune incompatibility. The experiments with adult stem cells harvested from individuals showed that cells which may be thought to be stem cells are, fortunately, present in many fully differentiated tissues, but they can evolve only into fully functioning cells of the same tissue. Their reprogramming was not taken into account. Recently, it has been shown that multipotent stem cells exist in various human tissues. This is true for bone marrow, brain, mesenchymal tissues or umbilical cord blood (7, 14, 37, 40). So, would adult stem cells used in cell therapy help to solve ethical problems associated with this method of therapy? Earlier, we called attention to the fact that outwardly these two methods differ because we can use autologous adult stem cells versus embryonic stem cells. On the outside, it is a good compromise and it seems that our ethical problem has been solved, but only till that time when all we need as "a minimum" is a multipotent stem cell (4). This is the moment where our vision of an ethical solution is fades out, because embryonic stem cell systems and adult stem cell systems are not in opposition but are closely related. 


\section{The questions of the methodologic use of Hippocratic oath}

Thinking of the above mentioned problems, we cannot omit the Hippocratic oath and its methodologic explanations. Not only that it is used till this day but for its theoretic and methodologic content determining medical and biological research.

The Hippocratic oath explicitly prompts a physician to treat in accordance with his conscience and knowledge to the advantage and benefit of a patient. The progress of medical knowledge cannot be stopped. It is possible to state that medicine belongs to the branches of human activities where incessant innovations in research, therapy, technology and methodology are always going on. The patient's benefit according to Hippokrates is all equipment and medicament applications up to the last encouraging smile. This all belongs to good medicine.

Research is the most delicate problem in investigating the methodology of the Hippocratic legacy. Research, in his time, cannot be compared with present level in both theory and equipment. Hippocrates did not speak about scientific empiricism, about experiments on biological models, but the conception of rational medicine cannot be excluded from his methodological legacy. Progress in medicine has gotten so far that scientific empiricism at the level of physician - researcher - patient is no more sufficient.

Medical research has reached the phase where, for example, a new method is tested and verified on the patient. That is why current discoveries go to the very base of human life, such as cloning $(22,23,42,49)$, and may have a great impact on the existence of man and society. These new possibilities heighten our feeling of respect for our existence. Our life, after all, is fragile and our existence, not endless.

The human embryo of a few hours or few days can be considered a specific multicellular formation of which an entite person may develop. However, the question of whether a surplus embryo produced in vitro dies unnecessarily still persists. If it serves for the benefit of the present generation and even future ones, perhaps Hippocrates would agree with continued research. There is the question of his words about the ban of giving medicine to a woman to induce abortion. Certainly, it is not the ban of experiments with surplus research embryos. Today's medicine indicates abortions when the mother's health is endangered and in other circumstances. Hippocrates himself does not solve the case of "research embryos." Perhaps only with a more conservative explanation of his text we would find refusal of the death of an embryo in any circumstance. But are we today interested in a rigorous explication of an archaic text? Certainly, not. We are interested in the real benefit of the patient treated with today's available means. With creative interpretation and progress in medicine, with concern for current and future ill human populations, the interpretation of Hippocratic principles must be more flexible, not that it would be a direct normative deontologic guidance, categorical imperative or denial. What directions shall we take in our search for ethical principles in modern medicine? Current ethics is not a discipline of just a "post factum" principle. It is an ever-increasing theoretic and prognostic discipline and without this claim of recognition it might end up being just part of history. It is good that it faces new and previously unknown problems the solution of which is sought in advance, maybe at the price of millions of expriments being be done to show that this is not the way to success. An ethical ban is not the result of a verified experimental error. There is no discovery without innovation and no benefit without courage. There, where we do no harm to a human being, Hippocrates may say: "Let us act, investigate and apply for the benefit of our patients and for prevention of disease as long as mankind is alive." According to the logic of evolution it is certain that we would not be the last species surviving others.

Initiated people are well aware that it cannot be a "solo run on a short track" of individual subjects or individual branches of human activities. At the present level of scientific reflection, neither philosophy nor medicine are able to create really usable axiology and ethics of their own with only their phenomenologic insight, experience or intuition. As both philosophical and medical ethics cannot be basically experimenting disciplines, there is no other way than to start again and again on new and yet unknown theoretic and methodologic interdisciplinary studies.

\section{Acknowledgements}

This work was supported by Research project MZO 00179906 and MSM0021620820.

\section{References}

1. Alikani M. The debate surrounding human embryonic stem cell research in the USA. Reprod Biomed Online 2007;15:7-11.

2. Annas GJ and Elias S. Politics, morals and embryos. Nature 2004;431:19-20.

3. Bok H, Schill KE, Faden RR. Justice, ethnicity, and stem-cell banks. Lancet 2004;364:118-121.

4. Camporesi S. The context of embryonic development and its ethical relevance. Biotechnol J 2007;2:1147-1153.

5. Clarke DL, Johansson CB, Frisén J, et al. Generalized potential of adult neura stem cells. Science 2000, 288:1660-1663.

6. Cohen CB. Stem cell research in the U.S. after the President's speech of August 2001. Kennedy Inst Ethics J 2004;1:97-114.

7. Committee on culture, science and education, Paliamentary Assembly of the Council of Europe. Human Reprod Genet Ethics 2004;10:53-67.

8. Denker HW. Human embryonic stem cells: the real challenge for research as well as for bioethics is still ahead of us. Cells Tissues Organs 2008;187:250-256.

9. Devolder K. What's in a name? Embryos, entities, and antities in the stem cell debate. J Med Ethics 2006;32:43-48.

10. De Wer G and Mummery Ch. Human embryonic stem cells: research, ethics and policy. Human Reprod 2003;18:672-682.

11. Doerflinger RM. The problem of deception in embryonic stem cell research. Cell Prolif 2008;41:65-70.

12. Ebbesen M, Pedersen BD. Using empirical research to formulate normative ethical principles in biomedicine. Med Health Care Philos 2007;10:33-48.

13. English V and Sommerville A. Presumed concept for transplantation: a dead issue after Alder Hey? J Med Ethics 2003;29:147-152.

14. Filip S, Mokrý J, English D, Vojáček J. Stem cell plasticity and issues of stem cell therapy. Folia Biologica (Prague) 2005:51:180-187.

15. Filip S, Mokrý J, Hruška I. Adult stem cells and their importance in cell therapy. Folia Biologica (Prague) 2003;49:9-14 
16. Filip S, English D, Mokrý J. Issues in stem cell plasticity. J Cell Mol Med 2004;8:572-577.

17. Filip S, Mokrý J, English D, Vojáček J. Stem cell plasticity and issues of stem cell therapy. Folia Biologica (Prague) 2005;51:180-187.

18. Fischbach GD and Fischbach RL. Stem cells: science, policy, and ethics. J Clin Invest 2004;114:1364-1370.

19. Hall SS. A lot of the problem we have in trying to develop these technologies for medicine is people's knee-jerk reaction to words like fetal and embryo. The New York Times Magazine. January, 2000;30:32-35

20. Hansen M, Bower C, Milne E, et al. Assisted reproductive technologies and the risk of birth defects a systematic review. Hum Reprod 2004;26:127-133.

21. Hurlbut WB. Ethics and embryonic stem cell research: altered nuclear transfer as a way forward. BioDrugs 2007;21:79-83.

22. Jeanisch R. Human cloning - the science and ethics of nuclear transplantation N Engl J Med 2004;351:2787-2791.

23. Knoepffler N. Stem cell research: an ethical evaluation of policy opinions. Kennedy Inst, Ethics J 2004;1:55-74.

24. Lanza R and Green RM. Bush's policy stopped US gaining stem-cell lead. Nature 2005;438:422.

25. Liew CG, Moore H, Ruban L, et al. Human embryonic stem cells: possibilities for human cell transplantation. Ann Med 2005;37:521-532.

26. Lippman A and Newman SA. The ethics of deriving gamets from ES cells Science 2005;307:515-51.

27. Lisker R. Ethical and legal issues in therapeutic cloning and the study stem cells. Arch Med 2003;34:607-611.

28. Marshal E. Ethicists back stem cells research, White house trends cautiously. Science 1999;285:502.

29. Marshal E. The business of stem cells. Science 2000;287:1419-1421.

30. Mc Laren, A. Stem Cells: Golden opportunities with ethical baggage. Science 2000;288:1778.

31. Mc Sorley SJ. It's not just theologians who are morally troubled. Nature 2005; 433:355.

32. Meeks DW. Bioethics, science, and politics. N Engl J Med 2004;351:298-300.

33. Merkel R. The legal status of the human embryo. Reprod Biomed Online 2007;14:54-60.

34. Mieth D. Stem cells: the ethical problems of using embryos for research. J Contemp Health Law Policy 2006;22:439-447.
35. Mokrý J, Karbanova J, Filip S. Differentiation potential of murine neural stem cells in vitro after transplantation. Transplant Proc 2005;37:268-272.

36. Nadir A. From the atom to the cell: is the cat alive? Quantum mechanics and stem cell plasticity as déja vu. Stem Cells Dev 2006;15:488-491.

37. Orlic DC, Bock TA, Kanz L. Hemopoietic stem cells: Biology and transplantation. Ann N Y Acad Sci 1999;872:405.

38. Parker C. Ethics for embryos. J Med Ethics 2007;33:614-616.

39. Pavelic K. Arguments for human therapeutic cloning. Bosn J Basic Med Sci 2004:4:15-18.

40. Pittenger MF, Mackay AM, Beck SC, et al. Multilineage potential of adult human mesenchymal stem cells. Science 1999;284:143-147.

41. Pomeau Y. Diffusion and reaction-diffusion in fast cellular flows. Chaos 2004;14:903-909.

42. Rusnak, A.J. and Chudley, A.E. Stem cell research: cloning, therapy and scientific found. Clin Genet 2006;70:302-305.

43. Sandel MJ. Embryo ethics-the moral logic of stem-cell research. N Engl J Med 2004;35:207-209.

44. Serafini $M$ and Verfaillie CM. Pluripotency in adult stem cells of the art. Semin Reprod Med 2006;24:379-388.

45. Sherly JL. The importance of valid disclosures in the human embryonic stem cell research debate. Cell Prolif 2008;41:57-64.

46. Spar D. The business of stem cells. N Engl J Med 2004;351:211-213.

47. Spyridonidis A, Zeiser R, Follo M, Metaxas Y, Finke, J. Stem cell plasticity: the debate begins to clarify. Stem Cell Rev 2005;1:37-43.

48. Stahnisch FW. Historical and philosophical perspectives on experimental practice in medicine and the life sciences. Theor Med Bioeth 2005;26:397-425.

49. Testa $G$ and Harris J. Genetics. Ethical aspects of ES cell-derived gametes. Science 2004;30:1719.

50. Thompson, J.A., Itskovitz-Eldor, J., Shapiro, S.S., et al. Embryonic stem cells lines derived from human blastocyts. Science 1998;282:1145-1147.

51. Towns CR and Jones DG. Stem cells embryos, and the environment: a context for both science and ethics. J Med Ethics 2004;30:410-413. Hum Reprod 2004;26:127-133.

52. Trouson AO. Future and application of cloning. Methods Mol Biol 2006; 348:319-332.

53. Van der Kooy D and Weiss S. Why stem cells? Science 2000;287:1439-1441.

Submitted December 2007. Accepted April 2008.

\section{Corresponding author:}

Prof. MUDr. Stanislav Filip, CSc., Department of Oncology and Radiotherapy, University Hospital Hradec Králové, Sokolská 548, 50005 Hradec Králové, Czech Republic, e-mail: filip@fnhk.cz 